\title{
New knowledge and the university
}

\author{
Martin Hall \\ Centre for Social Justice Research, University of Salford' \\ Martin.Hall@salford.oc.zo
}

\begin{abstract}
What forms of knowledge have legitimacy in the contemporary university? By using Actor-Network Theory to unravel the strands in a recent dispute about access to skeletons from a burial ground in Cape Town, this paper shows how circulating systems of references connect institutions, historical trajectories and differing sets of interests to form competing knowledge systems. Rather than falling back on a defence of established disciplines and academic authority, it is argued that there are considerable benefits in recognising the importance and validity of knowledge generated 'in community', and in the course of political discourse. Rather than undermining truth, such an approach will result in both better science and more informed community action.
\end{abstract}

Keywords: knowledge, university, actor-network-theory, physical anthropology, burials, community, memory

Between December 1913 and March 1914 Emile Durkheim delivered a series of fourteen lectures on the subject of Pragmatism and Sociology (Durkheim 1964). As the first Chair of the new discipline of Sociology at the Sorbonne, Durkheim was caught up in both the politics of curriculum reform and the wider issues of internationalism, nationalism and antiSemitism in a Europe a few months away from war. The theme of his lectures was the conflict between a long-established, conservative tradition of Rationalism, with its insistence on an absolute and independent concept of Truth, and the radical and aggressive pragmatism advanced primarily by US philosophers such as Peirce, Dewey and James, who argued for an experiential concept of reality.

Durkheim's concerns of a century ago mirror in many respects our own debates about knowledge and power, diversity and the relationship between 'science' and 'indigenous knowledge'. Nineteenth century academic establishments sought to exclude new and barbaric knowledge claims from new fields of study such as Sociology and English Literature and resisted curricula reforms. As Bourdieu (1996) famously demonstrated, universities characteristically have a double life, serving both as the gatekeepers to the establishment but also challenging and re-calibrating the boundaries of knowledge systems, enabling the creation of the new knowledge systems that are essential to intellectual progress. This double role was played out in the Sorbonne in Durkheim's time, in Bourdieu's France before, and after, the protests of 1968, and today.

But why evoke the ghost of Durkheim now? In a series of influential essays Johan Muller (2000) and subsequently Young and Muller (2007) have claimed Durkheim as the quintessential sociologist of the boundary, the defender of the 'sacred' knowledge of the established academy against the claims of ways of knowing that are constituted outside the university establishment. In this paper, through the use of a case study of conflicting knowledge claims in Cape Town, I want to show that such simple binaries of inclusion/ exclusion are an inappropriate way of characterizing how knowledge systems work in practice (as well as being a misrepresentation of Durkheim's position). Instead, we are in a phase of transition where the disciplinary certainties of high modernism are being replaced by hybrid knowledge fields and new networks of interconnection (Latour 1993). Rather than relying on status-based valorization (the primacy of the scientific expert, the authority of the professor), we need to look for opportunities for university-based knowledge systems to set up new networks of circulation that draw on ever-widening sources of information and expertise grounded in communities other than the academy.

Building on Bernstein's concepts of knowledge structures, Young. Muller and others insist on disciplinarity and the continued exclusion of the profane world from the academy (Bernstein 2000; Muller 2000; Young 2005; Young and Muller 2007, 2008). The decision on what constitutes legitimate knowledge rests with experts inside the academy: "truth and knowledge are fundamentally social categories - theories and facts about the world based on the best evidence and the most powerful theories as rationally arrived at by ... the inner community of scientists who can legitimately contribute to the rational consensus" (Young and Muller 2008: 519 ).

Muller and Young's position is in essence a defence of modernism in the face of various forms of relativism and arguments advocating the socially constructed nature of knowledge. Moving between the school curriculum and the sins of outcomes-based education and the role of the university in building and disseminating knowledge, their line of argument offers little comfort for ways of knowing loosely grouped together as "traditional", "indigenous", "community based" or "experiential". The modern university, from Kant through the rise of the great nineteenth century universities

1. The research for the paper was completed while the author was attached to the Centre for Leadership and Public Values, Graduate School of Business, University of Cape Town. 
to contemporary defenders of the established academy, is seen as a place apart where departmental boundaries must be defended against calls for problem-based research or the primacy of interdisciplinarity.

Writing some years before Muller, Bruno Latour (no friend of postmodernism or social constructivism, despite claims to the contrary) had identified the emerging crisis in this position (Latour 1993). Latour's argument is that vast achievements of science were based on a productive, but artificial, distinction between nature and society. While this device worked magnificently in establishing the foundations of advanced science and technology, the nature/society distinction is increasingly failing to explain or resolve contemporary issues of critical importance. Instead, the major challenges of the contemporary world are hybrid in character, requiring analysis and interpretation that is both social and scientific. Writing in the early 1990s, Latour is prescient in identifying some of these key hybrids. A definitive instance is global warming, where the "sacred" knowledges of environmental and political science are unable to deliver a solution that reconciles the valorization of democratic government with the consensus that, unless carbon emissions are reduced within the next decade, the consequences will be fatal for future governments. A current instance is the failure of the disciplinary structures of the academy to predict, or find solutions to, the partial collapse of the banking system, which has discredited, in the most experiential of ways, a vast paradigm of academic orthodoxy.

Latour's argument is not that modernism's achievements should be negated, and he has no time for 'absolute relativists', postmoderns or anti-modernists. He is rather arguing for the recognition of the key significance of hybrid systems, of ways of knowing that embody both science and the networks of associations which, for Latour, constitute the social (Latour 1993; 2005). While he is thinking here of Donna Haraway's cyborgs, or the combination of political associations and experimentation in which microbiology emerged (Haraway 1992; 1997; Latour 1999), Latour's work can equally be applied to the 'science' versus 'indigenous knowledge' debate, showing that the very distinction is invalid. Following Latour's insistence that the global can only ever be traced through the local, I will make this case through looking at the cries of despair of one group of scientists as they were denied access to their laboratory specimens, arguing that they should forget the recourse to sacred knowledge and should rather seek to understand the hybridism of the field in which they work and seek a politics that allows for differing interests and productive intersections between different ways of knowing.

Alan Morris's inaugural lecture in Human Biology, delivered at the University of Cape Town in October 2008 and published in part in the local press, was titled "The Politics of Old Bones" (Morris 2008). Morris's lecture was in part an overview of the field of Physical Anthropology, tracing its history from the racial obsessions of the nineteenth century through the disgrace of eugenics to contemporary work on the physical variability of human populations and the evidence of lifestyle revealed by skeletal analysis and chemical analysis of bone samples. But its main emphasis, and media interest, was a cri de coeur for the invasion of science by politics, the breaching of the boundaries of science by profane, popular interests.

The inaugural lecture is one of the formative rituals of disciplines, the assertion of the privileged status of university knowledge. Delivered in academic dress, before colleagues and students and without the opportunity for questions or debate, it is expected that the newly appointed or promoted professor will account for her or his intellectual antecedents, set out the scope of teaching and research and offer a programme for the future development of a field of study. Thus the professor professes and the boundaries of discipline are reviewed, revised and reasserted. This is Young and Muller's "inner community of scientists" reminding the world that they are the legitimate custodians of knowledge.

Morris argument was that Physical Anthropology had been "purified" (to use Latour's term) in the mid-twentieth century, following the excesses of colonialism and Nazi racial science, and has for the last half-century been a legitimate part of Human Biology: "the big break with the past came in 1951 when the United Nations published a statement on 'race' that rejected race science and the classification of human types on which it was based" (Morris 2008). However this rebirth has not been accepted by some outside the academy: "not everyone thinks that what I do for a living is respectable. For a significant and very vocal group here in Cape Town, anyone who studies the physical remains of humans is not a legitimate scientist. The cause of this is not what I have done, but what was done before me" (Morris 2008). For Morris, the social sciences are complicit in this process of misrepresentation: "there is a myth amongst social scientists that because physical anthropology no longer accepts the concept of race, that human variation somehow doesn't exit. This is a failure to understand current scholarship in the field and demonstrates an almost shameful ignorance of biology".

It is not common for an inaugural lecturer to both condemn public opinion and to denounce the work of another set of disciplines within the academy as "shameful". Clearly, the stakes were high. The scientific study of human remains has continued to be controversial long past the UN declaration of 1951 and has a complex history of controversy ranging from calls to repatriate parts of the collections of the British Museum, the rights of indigenous communities in Australasia and North America and, closer to home, to the return and reburial of the remains of Sara Baartman from the Musee de l'Homme in Paris. Such controversies have had a local history, with previous contestations concerning human burials in Cape Town and, of course, in other parts of South Africa as well (Malan 2008).

The particular events leading to Morris's inaugural statement started in May 2003 with the unearthing of a large burial ground in the course of the redevelopment of Prestwich Place, part of the older city of Cape Town along what had once been the foreshore. Long known as a part of town where the colony's underclass of slaves, dispossessed indigenes and marginalized were buried, such a discovery was bound to be controversia. The developer (Styleprops Ltd) duly notified the regulatory authority, the South African Heritage Resources Agency (SAHRA), and commissioned a recognized archaeological agency, the University of Cape Town's Archaeological Contracts Office (ACO), to carry out the 
required initial investigation and report. While not involved in the discovery and regulatory process, Morris and his team of science students from Human Biology made a robust claim for right of access to the 1200 or so skeletons unearthed at the site, and then applied to SAHRA for a permit to study the skeletons and take bone samples for chemical analysis. This application was turned down in April 2005 (Shepherd 2007).

For Morris, indignant at the continued association of his discipline with racial science and denied the opportunity of laboratory work and publication, this is a straightforward tale of truth versus ignorance, science versus prejudice and objectivity versus politics:

There was little debate about who was buried on the site, but a group of activists claimed 'ownership' on the basis of the poverty and exclusion of the people who were buried there. The public meetings, and more importantly the SAHRA facilitated meetings of 'interested parties', quickly deteriorated into slanging matches about who was going to benefit from the profits of the development. There were distinct racial overtones. The developer was seen as a white person about to make a financial killing by evicting the earlier oppressed people from the land in which they were buried. These same people were oppressed in life by the white colonial settlers and were now being oppressed in death by the same people. The demand of the activists was to stop all excavation and to turn the cemetery into a place of memorial ... The activists raised the old 'straw man' of the race scientist and bluntly refused to allow even the most basic assessment of who was buried on the site. My students and I tried everything we could to show them how we could decipher a wealth of information about health, lifestyle and demography from the skeletons, but to no avail (Morris 2008).

Prior to Morris's inaugural lecture, Antonia Malan and Nick Shepherd had published comprehensive and insightful analyses of the Prestwich Place story, the former in the context of community rights and the complexities of consultation and development, Shepherd as part of a larger project concerned with the politics of archaeological practice (Shepherd 2007, Malan 2008;). My purpose here is not to repeat their work, but rather to follow Latour in asking a somewhat different set of questions. If we see Morris's intellectual agony as a consequence of the larger fissures in the 'modernist settlement' as an inability to control the production of knowledge in the terms of a simple dichotomy between science and society - is there another way that the plot could have developed? Would it have been possible to have avoided the stark distinction between the sacred world of Human Biology and the profane world of those apparently mobilised against Science, admitting to the legitimacy of knowledge held and transmitted in the community and advanced and advocated via the public meetings and organizational networks aligned in opposition to the laboratory project?

Both Malan and Shepherd show that the Prestwich Place story is considerably more complex that the sacred/profane dichotomy presented by Morris. By using the methodology of
Actor-Network-Theory to take Malan and Shepherd's analyses further, this complexity can be mapped as sets of associations between actors (some human and some non-human) revealed through traces of objects, records, statements and other texts (Latour 2005). These networks bring the global into the local (for example, as Morris does by evoking the United Nations in his case for legitimate sampling of the Prestwich Place skeletons) and range across time (again, as Morris does by ranging across the history of his disciplines). As Latour has shown through his closely worked cases, such actor-networks are motivated by spokespersons who claim legitimacy in distinction to other actor-networks and constantly define legitimacy through coding knowledge and defining boundaries. Thus rather than seeing preordained domains of the sacred and profane, to understand knowledge production in terms of actor-networks is to prioritize the ethnographic observation of the complex intersections between science as a way of understanding the world and other, sometimes competing, systems of knowledge (Latour 2005).

Shepherd's close reading of the discovery and bringing to life of the key actors in the Prestwich Place story - the 1200 people previously buried there - shows the traces of three key actor-networks. For analytical convenience, we can call these 'Development', 'Memory' and 'Science' (although this is of course a device, since none would necessarily recognize the legitimacy of either of the others). Each evokes what Latour would call a 'panorama' - a legitimating view of an integrated world - and each would claim to represent a larger group (although it would be quite possible for an individual to be a member of more than one group). Further - and for the specific purposes of this discussion - each is aligned directly or indirectly with a set of academic disciplines.

Table I maps out these three actor-networks as a set of traces. For convenience, they are articulated by the key common event, the unearthing of the first of the Prestwich Place burials in May 2003. However, these are not the only intersections, and the traces of associations before and after May 2003 are not necessarily coterminous and range across time. Traces of the actor-networks similarly range across space, sometimes comprising intensely local records (for instance, the minutes of the first public meeting in St Stephen's Church) and at other times evoking a global archive (for example, international condemnation of Group Areas removals). The traces inventoried in Table I would be more fully expressed as a multidimensional set of radiating associations of highly variable length.

Since the group claims of Science have already found a prominent platform in Alan Morris's inaugural lecture, we will turn first to Development, barely visible in either Malan or Shepherd's accounts, and yet of key significance. To understand this actor-network it is necessary to reach beyond the obvious agency - Styleprops Ltd and the up-market urban apartments, the Rockwell, now completed and sold on the Prestwich Place site. The Development actor-network originates in theories of urban redevelopment, the need to reverse the middle class flight to the suburbs, to add-value, bulk up and ensure financial returns on investment in infrastructure. In this, the City of Cape Town, through its cohort of professional planners, committee structures and elected public representatives, follows the lead of cities in the west 
and north in the name of best practice. Urban redevelopment is enabled through local and international banks and commercial investors. The immediate manifestation of this widereaching set of associations and archive of company ownership, shareholdings, regulations and financial transfers is the proprietor of Styleprop Ltd, who purchased a rundown set of buildings with a great deal more below ground than he bargained for.

The trace of the Development actor-network continues past the key event - the unearthing of the first skeletons with exemplary attention to required process. The South African Heritage Resources Agency is duly notified as the legislation requires, and Styleprop Ltd picks up the fees due to the Archaeological Contracts Office, appointed to carry out the initial survey and write the first report. The interests of Styleprops Ltd, and indeed of the whole connected edifice of urban redevelopment and property investment are clear the skeletons must be exhumed and relocated under whatever regulatory regime and memorialisation process is deemed appropriate. While the proprietor of Styleprop, understandably, expresses anxiety from time to time, the trajectory of this group of actors is comparatively clear and uncomplicated by existential angst. Given property prices in up-market Cape Town at the time, it is likely that the costs of the delay and archaeological investigations were easily absorbed within the financial margins of the project. The Development actor-network continues to roll on, somewhat more alert after Prestwich Place, reinvesting profits in further urban regeneration in pursuit of the standing of a World City.

Morris dismisses the second actor-network set of associations - here labeled Memory for convenience - with a cursory condemnation as 'activists' who have a "shameful ignorance of biology" and who evoke a simplistic notion of race politics (Morris 2008). But Shepherd's earlier analysis, as well as subsequent writing by some of those most closely involved, shows that this is far from the case (Shepherd 2007). In order to understand this group of positions, it is again necessary to go beyond Shepherd's narrative and back to the consequences of forced removals conducted under the Group Areas Act from the 1960s onwards.

While many communities were displaced by apartheid legislation, the removal of more than 60000 people from District Six, and the bulldozing of entire blocks of houses on the east side of the Cape Town CBD, became iconic of the core human rights violations of the apartheid regime (Jeppie and Soudien 1990; Hall 2001; Rassool and Prosalendis 2001). In well documented histories of resistance, opposition crystallized in a range of civic organizations and, in particular, the Hands Off District Six Committee. After initially opposing the apartheid government, these civic organizations alsō stood against attempts by the City of Cape Town, allied with big business interests, to redevelop District Six as part of general urban development. This opposition has continued to the present, with community organizations at loggerheads with city planners and vociferous opposition to upmarket commercial and residential development on the fringes of District Six (Soudien 1990; 2008; Beyers 2005).

A second key outcome of the opposition to Group Areas removals was the establishment of the District Six Museum by former residents, committed to keeping memories of life in the suburb alive (Rassool and Prosalendis 200I). Through the powerful association of oral histories, material traces of everyday life before the bulldozers and continuing engagement with contemporary issues, the District Six Museum has become internationally renowned as an iconic community museum and memory project. It has long defined its role as reaching beyond the boundaries of District Six through engaging with the continuing consequences of dispossession and marginalization. There has been a close association between the work of the District Six Museum and academic work in oral history and heritage, particularly at the University of the Western Cape (Rassool 2008; Soudien 2008).

Far from being the anonymous and maligned 'activists' of Morris's account, then, those who engaged, by invitation, in the public meetings about Prestwich Place in 2005 had a long lineage of concern with memory, heritage and land rights, and a complex and often fraught relationship with the City of Cape Town's professional planning structures. They signaled this association through naming their coordinating group the Hands Off Prestwich Place Committee, and marked out continuity through the organizational structure of the District Six Museum (Weeder 2008). Because of the Anglican Church's long engagement with District Six, the Hands Off District Six Committee was able to mobilize the support of the then Archbishop of Cape Town (now, in a nice ironic twist, the Chair of the Council of the University of Cape Town).

Thirdly, then, the Science network. This position was put by the Archaeology Contracts Office and the Department of Archaeology at UCT during the public consultation process (Shepherd 2007) and - particularly - by Alan Morris in his inaugural lecture. This view - that there is an external truth awaiting discovery by a politically disinterested community of scientists using objective methodologies tested by proved theories - is of course widespread, and has been shown by Latour and others to be the core of the modernist settlement (Latour 1993)

Indeed, the 'panorama' of contemporary science is a powerful discourse that often drowns out other perspectives. As Table I summarises, the Science network that came into play around the Prestwich Place burial ground had in place, long prior to the unearthing of the first skeletons, a formal and comprehensive system of sampling and analytical techniques as well as a methodology of excavation protocol, stratigraphic interpretation and recording. This system of material traces and circulating references is similar in many respects to the techniques of soil science and botanical fieldwork painstakingly described by Latour in his now-classic account of science fieldwork at the Amazon forest edge (Latour 1999). These techniques were sufficiently well integrated with the regulatory protocols of the South African Heritage Resource Agency such that the 'Science machine' slipped easily into action once the discovery was reported, with the commissioning of the Archaeology Contracts Office under appropriate permits.

A key feature of actor-networks, however, and one that makes the approach particularly valuable for tracing how knowledge is created and generated, is that the incorporation of agents has unpredictable consequences. In this case, and for reasons to do with its unstable relationship between heritage and development interests, the South African Heritage 
Resource Agency stumbled, and permitted the continuing excavation and removal of burials from Prestwich Place during the statutory 60-day consultation period, rather than waiting to collect all opinions (Shepherd 2007). For reasons that will be explored further, this violation of required processes provided a focus of political action which, in Latour's terms, broke the system of circulating references definitive of the Science network. Outclassed in the rhetoric of public engagement, the science group of archaeologists and physical anthropologists lost access rights to the burials, and could therefore not complete the cycle of sampling, measurement, recordal and publication (shown in brackets in Table 1 to indicate unrealized aspirations).

Table I Prestwich Place: Actor-Networks

\begin{tabular}{|c|c|c|}
\hline Development & Memory & Science \\
\hline Panorama: integrated city development plan & $\begin{array}{l}\text { Panorama: continuity and comprehensiveness of } \\
\text { underclass repression }\end{array}$ & $\begin{array}{l}\text { Panorama: Integrity of non-political science based } \\
\text { knowledge }\end{array}$ \\
\hline Discipline: urban planning & Discipline: Historical Studies & Discipline: Physical Anthropology \\
\hline Group: urban planners, investors, developers & Group: church and community organizations & Group: scientists \\
\hline University: principles of urban planning & $\begin{array}{l}\text { Hands Off District Six opposition to Group Areas } \\
\text { redevelopment }\end{array}$ & General anthropological principles of research \\
\hline City of Cape Town urban development plans & $\begin{array}{l}\text { District Six Museum and material markers of mem- } \\
\text { ory }\end{array}$ & Agreed methods of sampling and bone analysis \\
\hline Banks and investors & Opposition to City urban renewal plans & Excavation techniques and protocols \\
\hline Styleprops Limited & Opposition to District Six property developments & \\
\hline Acquisition of Prestwich property & Prior conflicts over burials and international referents & \\
\hline Rockwell property development & University: heritage and oral history studies & \\
\hline Discovery of skeletons & Discovery of skeletons & Discovery of skeletons \\
\hline SAHRA notification & SAHRA public consultation & SAHRA permit regulation \\
\hline Commission to ACO & Public meeting: coordination and mobilization & Commission to $\mathrm{ACO}$ \\
\hline Removal of skeletons & Hands Off Prestwich Place Committee & Proposition for sampling, measurement and storage \\
\hline Memorialisation & Anglican Church engagement & (sampling and measurement) \\
\hline Sale of Rockwell apartments & District Six Museum engagement & (Recordal and archive) \\
\hline Monetarisation of value & (appropriation and memorialisation of burial ground) & (Publication) \\
\hline \multirow[t]{3}{*}{ Investment in next urban development project } & Appeal to SAHRA & (claim on IP through publication) \\
\hline & Appeal to Minister of Culture & (research grant, job offer, promotion) \\
\hline & Continuing opposition to urban development & Inaugural lecture: assertion of rights of science \\
\hline
\end{tabular}

It is by now clear that we are a long way from the simple story of good and evil presented in the rituals of disciplinary renewal of the inaugural lecture. The intersections of diverse communities of interest around the Prestwich Place burial ground has many implications of which several have particular interest in this discussion of the mechanics of knowledge construction. One is that, as Table I indicates, each of the three actor-networks incorporates the university as an institution. For the Science position, this is self-evident and asserted. But it is equally important for the Development network, which rests on a strongly integrated raft of professional education and certification in the planning, design and architecture disciplines, with disciplines such as Construction Economics and property studies and with legal education and qualification structures that codify the development and application of property law and rights. Similarly, the Memory network is reinforced and validated by Historical Studies, including theories and methodologies for working with oral histories, principles and ethical processes for community engagement and the broad, and expanding, field of critical heritage studies. These well-established disciplines and fields of study could be excused for responding to Alan Morris's complaint that they have a 'shameful' ignorance of biology with an equivalent complaint that Science seems to lack respect for the intellectual work of fellow academics who share their campuses.
The counterbalancing of the claims of Science with the imperatives of Memory is well articulated in a collection of essays that was published shortly after Morris's inaugural lecture, and which connect the long-standing work of the District Six Museum with the Hands Off Prestwich Place campaign (Bennett, Julius and Soudien 2008).

Here, Crain Soudien defines the core project of the District Six Museum as a specific and deliberate politics of remembering the City's past in ways that challenge assumptions of fixed racial identities, particularly by the City of Cape Town which, since re-development plans were first launched in the 1980s, has persisted in casting the rebuilding of District Six as a celebration of 'Coloured' identity (Soudien 2008). Soudien explains that opposing Science with community solidarity in the face of the proposed excavation and analysis of the Prestwich burial ground was a key part of this ongoing political project, particularly since the archaeological and anthropological processes claimed in the name of truth would render the disposed. dead "scientific objects of inspection" (Soudien 2008:28). This theme is further developed by Michael Weeder in the same set of essays. Weeder reviews the evidence for the extent and nature of burial grounds in colonial Cape Town and sees a similarity between the reification of the body of the slave as a thing of commercial value, and the proposed harvesting of samples from the Prestwich 
Place burials. "Ironically in the early 2 I st century, professional interests in the exhumed skeletal remains may inadvertently precipitate a similar propensity to separate experience from the facts of being. The dead of Prestwich Place were deemed to be archival resources to be forensically mined and interrogated" (Weeder 2008: 39).

Stepping back from the detailed issues that define the Prestwich Place conflict, the more general question - that brings together Muller, Young, Morris and a substantial number of those whom Latour has termed the 'Science Warriors' - is whether or not the District Six/ Hands Off Prestwich Place position is 'socially constructed', in the sense that meaning is ascribed according to contingent, political requirements, rather than by means of a rigorous, disciplined set of methodologies. Leaving aside for the moment what is understood by 'politics', what emerges from this close examination of the different positions on Prestwich Place is that the institutions engaged in 'memory work' deploy a set of methodologies for collecting, interpreting and synthesizing oral testimony, documentary sources and collections of objects that are as 'disciplined' as the biological and anthropological sciences. Thus Ciraj Rassool, both an academic and historian at the University of the Western Cape and a Trustee of the District Six Museum, describes the District Six Museum as "a hybrid space of research, representation and pedagogy, which has brokered and mediated relations of knowledge and varied kinds of intellectual and cultural practice between different sites, institutions and sociological domains" (Rassool 2008: 70). Indeed, as Latour has frequently pointed out, detailed studies of the ways in which meaning is generated as systems of circulating references brings the science laboratory and the oral history project into the same frame of understanding, and makes the dialectical opposition between 'science' and 'society' redundant (except as political rhetoric deployed by scientists to seek access to resources).

Seen in this way, what happened at Prestwich Place cannot be seen as a stand-off between Science-as-Truth and the dubiously-motivated rabble of the Prestwich Place public meetings. Rather, there are two systems of circulation, each incorporating a set of institutions (with some, such as the university, in common), texts (newspaper reports, science journals, the inaugural lecture etc) and, of course, the 1200 or so people buried at Prestwich Place.

There is also no inherent reason why these two systems of circulation should be in conflict, since their ultimate interests are quite different. Science seeks a continuing series of explanations of phenomena and scientists are motivated by the reputational benefits that come with publication and citation (David 1998). In this particular case, physical anthropologists and archaeologists wish to apply cutting-edge laboratory techniques to deduce epidemiological characteristics such as disease and nutrition. Memory work seeks to augment documentary evidence of the past, which favours the literate and powerful, with oral testimonies that better represent the lives of the underclass. In this particular case, historians and heritage practitioners wish to use such evidence in order to mobilize opinion against the continuing valency of raciallydeterministic categories and assumptions. Since physical anthropology no longer endorses the racial science that underpinned apartheid, and since it is in the interests of memory work to discover as much as possible about these underclass communities, it should be possible to map out an approach that would result in a productive intersection between these networks.

The difficulty is politics or, rather, the conceptualization of the political. For the District Six Museum (as a primary agent in this specific case) all memory work is inherently political. Soudien, Rassool, Bennett and others make this clear in their recently published collection of essays (Bennett, Julius and Soudien 2008) and Soudien sees the uncovering of the Prestwich Place burials as a political opportunity to challenge dominant discourses, in particular the determination of the City of Cape Town to perpetuate racialized identities in their urban planning assumptions (Soudien 2008). This is a clear demonstration of politics as "the progressive composition of the common world" (Latour 2005: 254) and is consistent with a wide range of definitions of what constitutes political work. In this case, this concept of the political reaches back over a century to the traditions of non-racialism and the Unity Movement.

In contrast, the 'Science Warriors' mobilise their common world, and claim access to influence and resources, by denying that their work is political in any sense. Thus in his inaugural lecture, Morris denounces those who oppose the claims of science to the bodies of the Prestwich Street dead as politically-motivated opponents of truth. Such denunciations are, of course, strongly political statements that lay claim to authority, decision-rights and primacy. The problem is that, in its very terms, this form of political claim denies the possibility of reconciliation with non-competing sets of interests.

But, as Shepherd and others have pointed out, there are well-tried and widely used alternatives to this confrontational approach that have been in place for many years. These archaeological and anthropological methodologies seek to implement what Bennett and Julius, in the context of the District Six Museum, call research 'in community' (Bennett and Julius 2008: 61). Here, for example, is Lynn Meskell introducing a set of "cosmopolitan archaeologies": "the past matters a great deal in the present and its material residues are increasingly crucial for imagining possible futures, particularly for developing beneficial trajectories based on the economic, political, and social potentials embedded within valued archaeological sites and objects" (Meskell 2009: 10). In one of these studies lan Lilley, reviewing the relationship between archaeological practice and indigenous communities in Oceana, argues that archaeologists need to move from being 'archetypal strangers' by reconciling the universalizing scientific tenets of archaeology and heritage management with local perspectives on the past. This will require forms of knowledge that are "functional and mutually rewarding hybrids" : "we advance the general proposition that the way that the physical landscape appears to Aboriginal people - its visual organization or structure - contains spiritual information concerning the organization or structure of the landscape that constrains people's behavior. This means, to give a simplified example, that if the landscape in a particular place looks like a snake, it actually is, in its spiritual guise, that snake and must be approached as such" (Lilley 2009: 56).

These and similar studies demonstrate the richness of interpretation that can follow from scientific research con- 
ducted 'in community'. Precedents have shown that it is quite feasible for archaeologists and physical anthropologists to negotiate with descendant communities for recording and measurement, and for sampling. Indeed, ethical protocols require this of all science research with human subjects, and no reputable human biologist would harvest samples from a recently deceased person without consent prior to death or the permission of immediate family. Similarly, a project to exhume and take samples from burials from demarcated graveyards in contemporary Cape Town would be inconceivable without engagement with religious communities and traceable family members and there is no clear reason why the Prestwich Place Burial Ground should have been treated differently (Weeder 2008). If such engagements were to align the interests of science with those of the memory community, the creation of new knowledge could be enhanced considerably. For example, historical epidemiology based on measurement, recording pathologies and bone sampling would yield broad indicators at the population level. For their part, oral histories would record traditions of food preparation, recurrent patterns of illness and qualitative aspects of life-expectancy and mortality. Such memories would constitute a rich, contextualized ethnography, invaluable for interpreting laboratory findings. In short, research negotiated and conducted 'in community' will be better research.

Were such a settlement to be attained for another of the burial grounds that lies beneath the still-unrenewed parts of Cape Town, where would this leave the distinction between sacred and the profane forms of knowledge, between the disciplined work of the academy and the far broader terrain of community-based and indigenous ways of knowing?

Rereading Durkheim almost a century after the foundations of sociological method were laid out evokes a sense of millennial parallel. Just as established nineteenth-century rationalism was confronted with New World pragmatism and its insistence on the significance of sense and experience, so are the monolithic academic disciplines of the twentieth-century university confronted with new and powerful forms of knowledge that thrive outside the academy. Muller and Young's response seeks to be to pull up the drawbridge and fall back on the authority of "the inner community of scientists who can legitimately contribute to the rational consensus" (Young and Muller 2008: 519). But Durkheim's response a century earlier was different.

Change, Durkheim argued, was inevitable: "our inclination to represent everything under the aspect of immutability is actually only an expediency. It is a means of giving the mind a sort of intellectual security. There are intellects that feel the need to base themselves on something fixed, to have a clearly drawn line of conduct that admits neither hesitation nor doubt, to tell themselves that there are no two ways of acting and thus no necessity to find out which of them is better. Such intellects need a ready-made discipline, a pre-established truth and code of laws. Otherwise they feel disoriented. All change, risk, and attempts at exploration cause them disquiet and uneasiness. Hence the tendency to believe in immutable truth and immutable realities is wholly natural. According to the pragmatists, this is the attitude that is characteristic of the rationalist mind: it represents a need for stability and assurance - in short, for repose" (Durkeim 1964:
4|3).

For Durkheim, as for the pragmatists, a static and immutable concept of truth was unacceptable. Durkheim's problem with the pragmatists was not that they violated discipline, stressed the importance of experience or sought to overturn the sacred world of the academy. It was rather that they argued for the primacy of individual experience rather than seeing the significance of the collective - of the regularities of human behavior through time and space that constituted the foundation of the sociological method. Indeed, pragmatism and sociology were interested in the same set of issues but, "if sociology poses the problem in the same sense of pragmatism, it is in a better position to solve it". This is because "the nature of the individual is too limited to explain by itself alone all things human". Pragmatism fails to recognize the "duality" between individual and collective experiences. "By contrast, sociology reminds us that what is social always possesses a higher dignity than what is individual ... The sociological point of view has the advantage of permitting us to analyze even the august thing that is truth" (Durkheim 1964: 429-430).

In Durkheim's sociology, progress stems from "the obliteration of individual differences". The social world comprises a set of institutions which, while changing, are also constant in their form. For the sociologist (as for the pragmatist), truth is variable: "intellectual life as well as practical life, and thought as well as action, need diversity, which is, consequently, a condition of truth ... it is in this way that the thesis enunciated by pragmatism is justified from the sociological point of view" (Durkheim 1964: 434). The difference between pragmatism and sociology lies in the mode of explanation. Pragmatism leads to arbitrary claims based on "a purely verbal definition that lacks an objective validity" (Durkheim 1964: 435). By implication sociology establishes objective validity through delineating the "higher order" of the collective.

When Durkheim's fourteen lectures on pragmatism are revisited, then, he emerges not as the defender of the sacred knowledge of the academy but as the quintessential modernist, speaking in the face of a Europe-wide war in which individual thought and action appeared powerless in the face of overwhelming social forces. His response was not to fall back on nineteenth-century rationalism, but was rather to absorb the energy and insight of the new pragmatist philosophy and to use it to move further in delineating the then-new field of sociological enquiry. Similarly today: the appropriate response to new knowledge claims and institutions is not to insist on the authority of the traditional and established disciplines (which now include Sociology) or to revert to claims for a politically-neutral, authoritative Science, but rather to look for the possibilities for revealing syncretisms, new institutional forms and hybrid approaches to knowledge construction.

\section{References}

Bennett, B., Julius, C. et al, eds. 2008. City. Site. Museum. Cape Town: District Six Museum.

Bennett, B. and Julius, C. 2008. 'Where is District Six? Between Landscape, Site and Museum'. In Bennett, B, C. Julius and C. Soudien, City. Site. pp. 52-67. Cape Town: District Six Museum.

Bernstein, B. 2000. Pedagogy, Symbolic Control and Identity: Theory, Research, Critique. Oxford:Rowman \& Littlefield.

Beyers, C. 2005. Land Restitution in District Six, Cape Town: 
Community, Citizenship and Social Exclusion. Brighton, University of Sussex.

Bourdieu, P. 1996. The State Nobility: Elite Schools in the Field of Power. Cambridge, Polity Press.

David, P. 1998. 'Communication Norms and the Collective Cognitive Performance of "Invisible Colleges"'. In Creation and Transfer of Knowledge: Institutions and Incentives. Edited by Navaretti G.B., K. Dasgupta, G. Maler and D. Siniscalco. pp I I5163. Heidelberg: Springer-Verlag.

Durkheim, E. 1964, 1913-1914. 'Pragmatism and Sociology'. In Essays on Sociology and Philosophy. Edited by Wolff, K.H. pp 386436. New York : Harper and Row

Hall, M. 2001. 'Cape Town's District Six and the Archaeology of Memory'. In The Destruction and Conservation of Cultural Property. Edited by Layton, R., P. Stone and J. Thomas. pp 29831 I. London: Routledge.

Haraway, D. 1992 'The Promise of Monsters: a Regenerative Politics for Inappropriate/d others'. In Cultural Studies. Edited by Grossberg, L., C. Nelson and P.A. Treichler. pp 295-37. London: Routledge.

Haraway, D. 1997. Modest_Witness @ Second_Millennium.Female Man Meets OncoMouse. London: Routledge.

Jeppie, S. and Soudien, C. (eds.) 1990. The Struggle for District Six: Past and Present. Cape Town: Buchu Books.

Latour, B. 1993. We Hove Never Been Modern. Cambridge: Harvard University Press.

Latour, B. 1999. Pondora's Hope: Essays on the Reality of Science Studies. Cambridge: Harvard University Press.

Latour, B. 2005. Reassembling the Social: an Introduction to ActorNetwork-Theory. Oxford: Oxford University Press.

Lilley, 1. 2009. 'Strangers and Brothers? Heritage, Human Rights and Cosmopolitan Archaeology in Oceana'. In Cosmopolital Archaeologies. Edited by Meskell, L. pp 48-67. Durham: Duke University Press.

Malan, A. 2008. Contested Sites: Negotiating New Heritage Practice in Cape Town. Journal for Islamic Studies 24 \& 25: 17-52.

Meskell, L. 2009. 'Introduction: Cosmopolitan Heritage Ethics'. In
Cosmopolital Archoeologies. Edited by Meskell, L. PP 1-27. Durham: Duke University Press.

Morris, A.G. 2008. Inaugural Lecture: The Politics of Old Bones. Cape Town: University of Cape Town.

Muller, J. 2000. Reclaiming Knowledge: Social Theory, Curriculum and Education Policy. London: Routledge.

Rassool, C. and Prosalendis, S. (eds.) 2001. Recalling Community in Cape Town: Creating and Curating the District Six Museum. Cape Town: District Six Museum Foundation.

Rassool, C. 2008. 'Contesting 'Museumness': Towards an Understanding of the Values and Legacies of the District Six Museum'. In City. Site. Museum. Edited by Bennett, B. C. Julius and C. Soudien. pp 68-75. Cape Town: District Six Museum.

Shepherd, N. 2007. Archaeology Dreaming: Post-apartheid Urban Imaginaries and the Bones of the Prestwich Street Dead. Journal of Social Archaeology 7(1): 3-28.

Soudien, C. 1990. 'District Six: from Protest to Protest'. In The Struggle for District Six: Past and Present. Edited by Jeppie, S. and C. Soudien. pp 143-183. Cape Town: Buchu Books.

Soudien, C. 2008. 'Memory in the Remaking of Cape Town'. In City. Site. Museum. Edited by Bennett, B., C. Julius and C. Soudien. pp: |8-3| Cape Town: District Six Museum.

Weeder, M. 2008. 'Topographies of the Forgotten: Prestwich and Cape Town's Nineteenth Century Cemeteries'. In City. Site. Museum. Bennett, B., C. Julius and C. Soudien. pp 32-49. Cape Town: District Six Museum.

Young, M. 2005. The Knowledge Question and the Future of Education in South Africa: A Reply to Michelson's 'On Trust, Desire, and the Sacred: A response to Johan Muller's Reclaiming Knowledge'. Journal of Education 36: 7-17.

Young, M. and Muller J. 2007. Truth and Truthfulness in the Sociology of Educational Knowledge. Theory and Research in Education 5(2): 173-201.

Young, M. and Muller, J. 2008. The Cosmic Community: A Response to Maria Balarin's 'Post-structuralism'. Policy Futures in Education 6(4): 506-518. 
Copyright of Anthropology Southern Africa is the property of Foundation for Education Science \& Technology and its content may not be copied or emailed to multiple sites or posted to a listserv without the copyright holder's express written permission. However, users may print, download, or email articles for individual use. 